\title{
PERKEMBANGAN OJEK ONLINE DIKOTA BANJARMASIN
}

Widarto, Rijalul Gadi, dan Singgih Priono

widartobinabanua@gmail.com

Sekolah Tingggi Ilmu Administrasi (STIA) Bina Banua

\begin{abstract}
The purpose of the research is to know the development of Ojek line, knowing the factors that inhibit the development of Ojek on line and to know the factors that support the development of Ojek on line in Banjarmasin City

This research uses descriptive methods. Key informant in this case is the employee who came from the Department of Communication and Informatics of Banjarmasin City, while the informant is the users of taxi services on line and the perpetrator Ojek on line. To sharpen research derived from two sources, sourced from primary data, primary data obtained from interviews with key informant and informant, so that the data according to the problems studied, the second source is the data seconder. Development on line Ojek in the city of Banjarmasin has increased year after year, nevertheless the Ojek on line is still not fully handled by the Office of Communication and Informatics communications, so that there is no accurate data Number of Ojek on line this.

The supporting factor of the existence of the Ojek on line is seen from several aspects, namely from the economic aspects, Ojek on line Create new jobs, so as to increase the income of members of the community, in terms of social, ojek on line will Reducing unemployment rate, reducing traffic flow congestion. In terms of law, there are legislation that is used as the basis for the operation of Ojek on line.

The factor that has taken the development of Ojek on line is seen in terms of legal aspects is the absence of regional regulations that can be used as a reference to act on Ministerial Regulation 108 year 2017 on the transport of people Transportation Public motor is not on the route, including instructions and technical instructions, in addition, also comes from members of the community who still use the traditional ojek, so that the Ojek on line is not moving freely.
\end{abstract}

Keywords: Developing, transportation online 
Volume 5 Nomor 1, April 2019

\section{PENDAHULUAN}

Pembangunan yang sedang gencar-gencarnya dilaksanakan oleh pemerintah pada saat ini adalah pembangunan bidang transportasi, pembangunan bidang transportasi dengan melakukan penyediaan prasarana dan sarana tranportasi, baik di darat, laut maupun udara, karena dengan penyediaan prasarana dan sarana transportasi ini dapat menghubungkan antara daerah yang satu dengan daerah yang lain, hal ini dilakukan agar daerah-daerah tertentu tidak terisolasi dengan daerah yang lainnya, sehingga tidak terjadi kepincangan pembangunan antara daerah yang satu dengan daerah yang lainnya

Pemerintah pusat maupun daerah mempermasalahkan tentang membludaknya angkutan dalam jaringan baik ojek sepeda motor online maupun taksi online. Oleh karena itu diperlukan adanya dasar hukum yang dapat dijadikan pedoman dalam pelaksanaannya, sehingga terjadi adanya benturan antara angkutan konvensional dengan angkutan yang menggunakan jaringan online. Belum lagi antara perusahaan jaringan yang satu dengan perusahaan jaringan yang lain, bahkan bisa berakibat fatal. Hal ini harus dicarikan jalan keluarnya. Salah satu cara untuk meminimalisasinya adalah pemerintah mengeluarkan Peraturan Menteri No 108 tahun 2017 tentang penyelanggaraan bermotor umum tidak dalam trayek.

Keberadaan ojek sepeda motor sendiri bisa dikatakan sangat dibutuhkan oleh masyarakat walaupun sampai saat ini tarif yang dikenakan masih tidak sebanding dengan jarak yang ditempuh, dan gojek sampai saat ini masih belum dipayungi oleh hukum yang mengaturnya, karena masih adanya penundaan berlakunya Peraturan Menteri No 108 tahun 2017 tentang penyelenggaraan bermotor umum tidak dalam trayek, hal ini tentu saja merugikan pelaku Gojek, baik sebagai obyek maupun sebagai subyek, berdasarkan hal inilah maka penelitian sangat perlu dilakukan dengan harapan dapat memecahkan permasalahan yang dihadapi.

Tarif dan jarak yang ditempuh oleh pelaku Gojek sebagian besar tidak sebanding dengan yang seharusnya dan masih adanya penundaan berlakunya Peraturan Menteri No 108 tahun 2017 tentang penyelenggaran bermotor umum tidak dalam trayek. Alih-alih memberlakukan peraturan tersebut, pemerintah menjanjikan peraturan baru yang melibatkan driver online dalam perumusannya tetapi pemerintah mengatakan bahwa 
Volume 5 Nomor 1, April 2019

Permenhub 108 tetap berlaku. Hal ini diduga akan membuat driver Gojek kecewa dan akan tetap meneruskan aksi demo. Permasalahan ojek on line ini sampai saat menjadi perhatian yang serius, oleh karena itu, penelitian kearah perkembangan ojek on line perlu untuk diteliti, sehingga segala permasalahan-permasalahan yang berhubungan dengan ojek on line dapat dipecahkan.

\section{TINJAUAN TEORITIS}

\section{Administrasi Negara}

Administrasi adalah keseluruhan proses kerjasama antara dua orang atau lebih yang didasarkan atas rasionalitas tertentu dalam rangka pencapaian tujuan yang telah ditentukan sebelumnya dengan memanfaatkan sarana dan prasarana tertentu secara berdaya guna dan berhasil guna (Hadari Nawawi, 2010:2).Sukarna (2011:1) administrasi adalah segala kegiatan untuk mencapai tujuan yang telah ditentukan. S.P. Siagian (2011:3) administrasi adalah keseluruhan proses kerjasama antara dua orang atau lebih yang didasarkan atas rasionalitas tertentu untuk mencapai tujuan yang telah ditentukan sebelumnya.Perwujudan nyata terdapat perbedaan dalam penerapan prinsip, rumus, dalil dalam bidang kenegaraan dibandingkan dengan bidang keniagaan, adanya perbedaan tersebut disebabkan oleh :

a. Faktor tujuan

Administrasi negara bertujuan untuk meningkatkan kemakmuran seluruh rakyat, sedangkan administrasi niaga untuk mengusahakan kelangsungan hidup organisasi niaga.

b. Faktor motif

Administrasi negara dalam proses pelaksanaan kegiatan bermotifkan pemberian service yang effesien, ekonomis, dan effektif mungkin kepada setiap warga negara, sedangkan administrasi niaga dalam operasinya bermotiflan keuntungan yang wajar atas modal yang telah diinvestasikan.

c. Sifat pelayanan

Administrasi negara berkewajiban melayani semua warga negara dengan perlakuan yang sama, karena warga negara di bidang hukum memiliki kedudukan yang sama, sedangkan administrasi niaga membeakan sifat service yang diberikan, karena 
Volume 5 Nomor 1, April 2019

motifnya untuk mencari keuntungan, sehingga siapa yang memberi keuntungan paling besar mendapat pelayanan yang terbaik.

d. Wilayah yuridiksi

Administrasi negara mempunyai wilayah sama luasnya dengan wilayah kekuasaan negara, sedangkan administrasi niaga tidak memiliki wilayah kekuasaan, yang dimiliki hanya wilayah operasi, yang wilayahnya dapat lebih kecil dari negara, sama dengan negara, bahkan lebih luas dari wilayah kekuasaan negara.

e. Kekuasaan

Administrasi negara memperoleh kekuasaan dari rakyat melalui lembaga perwakilan, sedangkan administrasi niaga memperoleh kekuasaan dari besarnya modal, keterampilan.

f. Orientasi politik

Administrasi negara dan seluruh aparatur negara sebagai abdi dari rakyat yang beorientasi politik netral, pada administrasi niaga selalu memihak atau menganut suatu aliran yang dianggap dapat membantu usahanya dalam mengabdikan kehidupan organisasi.

g. Cara Bekerja

Administrasi negara dalam prosesnya lamban karena berdasarkan pada pendekatan legalitas, sedangkan administrasi niaga lebih menekankan pada pendekatan programatis, karena selalu dihadapkan pada kompetesi atau persaingan sehingga harus bersifat inovatif. (Sondang. P. Siagian, 2013:30-33)

\section{Adminstrasi Transportasi.}

Kamaludin (1987) dalam Romli (2012:34), Transportasi berasal dari kata latin tranpotare, dimana tran berarti seberang atau sebelah dan portare berarti mengangkut atau membawa. Jadi tansportasi berarti mengangkut atau membawa (sesuatu) kesebelah lain atau dari satu tempat ke tempat lainnya.

Tamin (2013:67), Transportasi adalah suatu sistem yang terdiri dari prasarana/sarana dan sistem pelayanan yang memungkinkan adanya pergerakan keseluruh wilayah sehingga terakomodasi mobilitas penduduk, dimungkinkan adanya pergerakan barang, dan dimungkinkannya akses kesemua wilayah. Sedangkan fungsi trasportasi, Morlok (2013:23) adalah untuk menggerakan atau memindahkan orang 
dan/atau barang dari satu tempat ke tempat lain dengan menggunakan sistem tertentu untuk tujuan tertentu.

Salim (2013:45) transportasi adalah kegiatan pemindahan barang (muatan) dan pengguna jasa dari suatu tempat ke tempat lain. Dalam transportasi ada dua unsur yang terpenting yaitu pemindahan/pergerakan (movement) dan secara fisik mengubah tempat dari barang (comoditi) dan pengguna jasa ke tempat lain.

Hasim Purba (2011:7), pengangkutan adalah kegiatan pemindahan orang dan atau barang dari suatu tempat ke tempat lain baik melalui angkutan darat, angkutan perairan maupun angkutan udara dengan menggunakan alat angkutan. Jadi pengangkutan itu berupa suatu wujud kegiatan dengan maksud memindahkan barangbarang atau pengguna jasa (orang) dari tempat asal ke suatu tempat tujuan tertentu.

Soegijatna Tjakranegara (2013:45), pengangkutan adalah memindahkan barang atau-commodity of goods dan pengguna jasa dari suatu tempat ketempat lain, sehingga pengangkut menghasilkan jasa angkutan atau produksi jasa bagi masyarakat yang membutuhkan untuk pemindahan atau pengiriman barang-barangnya.

Utomo (2013:33), transportasi adalah pemindahan barang dan manusia dari tempat asal ke tempat tujuan. Sedangkan Sukarto (2012:43), transportasi adalah perpindahan dari suatu tempat ke tempat lain dengan menggunakan alat pengangkutan, baik yang digerakkan oleh tenaga manusia, hewan (kuda, sapi, kerbau), atau mesin. Konsep transportasi didasarkan pada adanya perjalanan (trip) antara asal (origin) dan tujuan (destination).

Transportasi manusia atau barang biasanya bukanlah merupakan tujuan akhir, oleh karena itu permintaan akan jasa transportasi dapat disebut sebagai permintaan turunan (derived demand) yang timbul akibat adanya permintaan akan komoditi atau jasa lainnya. Dengan demikian permintaan akan transportasi baru akan ada apabila terdapat faktor- faktor pendorongnya. Permintaan jasa transportasi tidak berdiri sendiri, melainkan tersembunyi dibalik kepentingan yang lain. (Molok, 2013:56).

Fungsi transportasi, Morlok (2013:64) adalah untuk menggerakan atau memindahkan orang dan / atau barang dari satu tempat ke tempat lain dengan menggunakan system tertentu untuk tujuan tertentu.

Utomo (2013:43), transportasi memiliki fungsi dan manfaat yang terklasifikasi menjadi beberapa bagian penting. Transportasi memiliki fungsi yang terbagi menjadi 
Volume 5 Nomor 1, April 2019

dua yaitu melancarkan arus barang dan manusia dan menunjang perkembangan pembangunan (the promoting sector). Sedangkan manfaat transportasi menjadi tiga klasifikasi yaitu:

a. Manfaat Ekonomi

Kegiatan ekonomi bertujuan memenuhi kebutuhan manusia dengan menciptakan manfaat. Transportasi adalah salah satu jenis kegiatan yang menyangkut peningkatan kebutuhan manusia dengan mengubah letak geografis barang dan orang sehingga akan menimbulkan adanya transaksi.

b. Manfaat Sosial

Transportasi menyediakan berbagai kemudahan, diantaranya 1) pelayanan untuk perorangan atau kelompok, 2) pertukaran atau penyampaian Informatika, 3) Perjalanan untuk bersantai, 4) Memendekkan jarak, 5) Memencarkan penduduk.

c. Manfaat Politis

Transportasi menciptakan persatuan, pelayanan lebih luas, keamanan negara, mengatasi bencana, dll.

d. Manfaat Kewilayahan

Memenuhi kebutuhan penduduk di kota, desa, atau pedalaman.

\section{METODOLOGI PENELITIAN}

Penelitian ini menggunakan metode deskriptif. Key informan dalam hal ini adalah pegawai yang berasal dari Dinas Perhubungan Komunikasi dan Informatikakota Banjarmasin, sedangkan informan adalah para pengguna jasa angkutan ojek on line dan pelaku ojek on line. Untuk mempertajam penelitian berasal dari dua sumber, yaitu bersumber dari data primer, data primer diperoleh dari hasil wawancara dengan key informan dan informan, sehingga data sesuai dengan permasalahan yang diteliti, sumber yang kedua adalah data skunder, data ini diperoleh dari dokumen-dokumen yang ada hubungan dengan permasalahan yang diteliti

Teknik pengumpulan data yang digunakan dalam penelitian ini, yaitu dengan metode wawancara, observasi, dokumentasi, sedangkan teknik analisa data yang digunakan adalah analisa kualitatif. 


\section{HASIL PENELITIAN DAN PEMBAHASAN Perkembangan Ojek Online di Kota Banjarmasin}

Kota Banjarmasin merupakan salah satu kota yang dianggap dapat mengembangkan suatu usaha, maka pada awal tahun 2015 alat angkutan umum on line diakui keberadaannya, angkutan umum on line ini terdiri dari kendaraan bermotor roda dua dan kendaraan bermotor roda empat, yang kesemuanya itu dapat dikatakan sebagai ojek. Ojek adalah sepeda atau sepeda motor yang disewakan dengan cara memboncengkan penyewanya, hal ini berdasarkan dari wawancara yang telah dilakukan kepada pelaku ojek pada tanggal 15 Juni 2018 dengan mengatakan sebagai berikut.

Ojek on line terdiri dari kendaraan bermotor roda dua dan kendaraan bermotor roda empat, namun pengguna jasanya berbeda, kemdaraan bermotor roda dua hanya untuk satu orang, sedangkan kendaraan bermotor roda empat untuk lebih dari satu orang, demikian pula dengan tujuan, kendaraan bermotor roda dua dapat mengantarkan sampai ke tujuan (rumah) sedangkan kendaran bermotor roda empat hanya mengantar pada jalur yang hanya dapat dilalui kendaraan roda empat.

Berdasarkan pada hasil wawancara tersebut maka ojek terdiri dari dua jenis, yakni kendaraan bermotor roda dua dan kendaraan bermotor roda empat, dimana ojek ini sama-sama mengantar pengguna sampai pada tujuan, walaupun demikian ojek kendaraan roda empat mengantarkan pengguna hanya sampai pada jalur yang hanya dapat dilalui kendaraan roda empat, demikian pula dengan jumlah pengguna, kendaraan roda empat dapat digunakan lebih dari satu orang.

Berdasarkan Pasal 1 angka 20 UULLAJ, menyatakan bahwa sepeda motor adalah kendaraan bermotor beroda dua dengan atau tanpa rumah-rumah. Ojek merupakan sarana transportasi darat yang menggunakan kendaraan roda dua (sepeda motor) untuk mengangkut pengguna jasa dari satu tujuan ke tujuan lainnya kemudian menarik bayaran.

Ojek yang merupakan kendaran motor roda dua ini memang transportasi yang sangat efektif untuk mobilitas di kemacetan kota. ojek modern berbasis pesanan. PT GO-JEK Indonesia yang sudah melewati perjalanannya sejak tahun 2011.

Saat itu, layanan yang ditawarkan GO-JEK meliputi transportasi, kurir, dan berbelanja. Tujuan PT GO-JEK saat itu adalah meningkatkan kinerja para pengemudi 
ojek. Di 2015 PT GO-JEK memutuskan untuk menyediakan layanan GO-JEK dalam bentuk aplikasi. Sehingga GO-JEK menjadi sebuah solusi berbasis teknologi yang memudahkan segala kebutuhan kehidupan sehari-hari masyarakat. Di sinilah pertumbuhan GO-JEK menjadi sangat signifikan. Ketika aplikasi GO-JEK diluncurkan pada tahun 2015, ada tiga layanan yang ditawarkan yaitu transport, instant courier, dan shopping.

GO-JEK menawarkan 8 (delapan) fitur jasa layanan yang bisa dimanfaatkan oleh para pelanggannya yaitu Go-Send (Pengantaran Barang), Go-Ride (Jasa Angkutan Orang), Go-Food (Pesan Makanan), Go-Mart (Belanja), Go-Glam, Go-Massage, GoBox, Go-Clean, Go-Busway, dan Go-Tix yang menekankan keunggulan dalam kecepatan, inovasi dan interaksi sosial.

Berdasarkan pasal 1 angka 10 UULLAJ jo pasal 1 angka 5 PP Nomor 74 Tahun 2014 tentang Angkutan Jalan menyatakan bahwa kendaraan bermotor umum adalah setiap kendaraan bermotor yang digunakan untuk angkutan orang dan/atau dengan dipungut biaya.

Wawancara yang dilakukan kepada pelaku ojek pada tanggal 19 Juni 2018, bahwa ojek on line mempunyai keunggulan dan keunikan tersendiri, karena keunggulan ini tidak dimiliki oleh ojek tradisional, demikian pula dengan keunikannya.

Ojek sepeda motor dikatakan sebagai angkutan orang dengan kendaraan bermotor roda dua. Tidak diatur secara khusus mengenai sepeda motor sebagai angkutan kendaraan bermotor umum, karena ada beberapa permasalahan dalam administrasi pendaftaran ojek sebagai kendaraan bermotor umum di Dinas Perhubungan.

Pengangkutan adalah perjanjian timbal balik antara pengangkut dengan pengguna jasa, dimana pengangkut mengikatkan diri untuk menyelenggarakan pengangkutan barang dan/atau orang dari suatu tempat ke tempat tujuan tertentu dengan selamat, sedangkan pengirim dan/atau pengguna jasa mengikatkan diri untuk membayar membayar angkutan.

Proses pengangkutan itu merupakan gerak dari tempat asal dari mana kegiatan angkutan dimulai ke tempat tujuan di mana angkutan itu diakhiri. pengangkutan pada pokoknya berisikan perpindahan tempat baik mengenai benda maupun mengenai orang, karena perpindahan itu mutlak perlu untuk mencapai dan meninggikan manfaat serta 
efisiensi. Adapun proses dari pengangkutan itu merupakan gerakan dari tempat asal dari mana kegiatan angkutan dimulai ke tempat tujuan dimana angkutan itu diakhiri.

Pengguna jasa (passanger) adalah pihak yang berhak mendapatkan pelayanan jasa angkutan dan berkewajiban untuk membayar tarif (ongkos) angkutan sesuai dengan yang ditetapkan. Ada beberapa ciri pengguna jasa :

a. Orang yang berstatus pihak dalam perjanjian pengangkutan.

b. Membayar biaya angkutan.

c. Pemegang dokumen angkutan.

Dalam pasal 1 angka 25 UU Nomor 22 tahun 2009 yang dimaksud pengguna jasa adalah orang yang berada di kendaraan selain pengemudi dan awak kendaraan dengan mengikatkan diri setelah membayar uang atau tiket angkutan umum sebagai kontraprestasi dalam perjanjian pengangkutan, dengan demikian maka seseorang telah sah sebagai pengguna jasa angkutan umum.

Dalam peraturan perundang-undangan di Indonesia, istilah pengguna jasa sebagai definisi yuridis formal ditentukan pada undang-undang Nomor 8 tahun 1999 tentang perlindungan pengguna jasa (selanjutnya disingkat UUPK). UUPK pasal 1 angka 2 menyatakan, pengguna jasa adalah setiap orang pemakai barang dan/atau jasa yang tersedia dalam masyarakat, baik bagi kepentingan diri sendiri, keluarga, orang lain maupun makhluk hidup lainnya dan tidak diperdagangkan.

Demi terciptanya tertib administrasi dan tertib hukum dalam penyelenggaraan pengangkutan, pemerintah melalui kementrian perhubungan selaku otoritas yang memiliki kewenangan penuh dalam bidang penyelenggaraan pengangkutan di Indonesia menetapkan regulasi bagi barang siapa yang bertindak sebagai pengangkut agar dianggap dalam menjalankan peranannya tersebut.

Penyelenggaraan pengangkutan oleh pengangkut dianggap telah sah dan layak setelah memenuhi persyaratan, yaitu memiliki ijin usaha angkutan, mengasuransikan orang dan/atau barang yang diangkut serta layak pakai bagi kendaraan yang dioperasikannya.

Pengangkutan terkait dua pihak, yaitu pengangkut dan pengirim barang atau pengguna jasa. Jika tercapai kesepakan diantara para pihak, maka pada saat itu lahirlah perjanjian pengangkutan, apabila pengangkut dengan pengirim telah melakukan perjanjian penyelenggaraan pengangkutan barang atau pengguna jasa, pengangkut telah 
terikat pada konsekuensi-konsekuensi yang harus dipikul oleh pengangkut berupa tanggung jawab terhadap pengguna jasa dan muatan.

Tanggung jawab pengangkut lahir ketika pengguna jasa mengalami kerugian atas kelalaian pengemudi dan pengemudi bertanggung jawab atas kerugian yang diderita pengguna jasa dan/atau pemilik barang yang timbul karena kesalahan pengemudi dalam mengemudikan kendaraan bermotor.

Kewajiban pengangkut adalah menyelenggarakan pengangkutan, dari kewajiban itu timbul tanggung jawab pengangkut, maka segala sesuatu yang mengganggu keselamatan pengguna jasa atau barang barang tersebut yang merugikan pengguna jasa dan/atau barang menjadi tanggung jawab pengangkut. Dengan demikian, pengangkut berkewajiban menanggung segala kerugian yang diderita oleh pengguna jasa dan/atau barang yang diangkut tersebut. Wujud tanggung jawab tersebut adalah ganti rugi (kompensasi)engangkutan terdapat empat (4) prinsip atau ajaran dalam menentukan tanggung jawab pengangkut, yaitu sabagai berikut:

a. Prinsip tanggung jawab atas dasar kesalahan (the based on fault atau liability based on fault principle)

Prinsip ini setiap pengangkut yang melakukan kesalahan dalam penyelenggaraan pengangkutan harus bertanggung jawab membayar ganti kerugian yang timbul akibat dari kesalahan itu, pihak yang menderita kerugian harus membuktikan kesalahan pengangkut itu. (Pasal $1365 \mathrm{BW}$ )

b. Prinsip tanggung jawab atas dasar praduga (presumption of liability principle)

Prinsip ini pengangkut dianggap selalu bersalah kecuali pengangkut dapat membuktikan bahwa dirinya tidak bersalah atau dapat mengemukakan hal-hal yang dapat membebaskan dari kesalahan. Beban pembuktian menjadi terbalik yaitu pada pengangkut untuk membuktikan bahwa pengangkut tidak bersalah.

c. Prinsip tanggung jawab mutlak (no fault, atau strict liability, absolute liability principle)

Pengangkut harus bertanggung jawab membayar ganti kerugian terhadap setiap kerugian yang timbul dari pengangkut yang diselenggarakan tanpa keharusan pembuktian ada tidaknya kesalahan pengangkut. Pengangkut tidak dimungkinkan membebaskan diri dari tanggung jawab dengan alasan apapun yang menimbulkan kerugian itu. Prinsip ini tidak mengenal beban pembuktian tentang kesalahan, unsur 
Volume 5 Nomor 1, April 2019

kesalahan tidak relevan untuk dipermasalahkan apakah pada kenyataannya ada atau tidak

d. Prinsip Praduga untuk tidak selalu bertanggung jawab (Presumption Of Non Liability Principle)

Prinsip ini hanya dikenal dalam lingkup transaksi pengguna jasa yang sangat terbatas, dan pembatasan demikian biasanya secara common sense dapat dibenarkan.

Pengangkutan ini terdapat permasalahan antara pengguna jasa dengan pelaku ojek, diantaranya adalah tentang biaya yang harus dikeluarkan oleh pengguna jasa, karena yang diminta dengan yang dibayar tidak sesuai, hal ini diperkuat oleh pengguna jasa on line pada saat dilakukan wawancara pada tanggal 21 Juni 2018 dengan mengatakan sebagai berikut :

Pengguna jasa membayar ongkosnya sesuai dengan apa yang ada di Informatika handphonenya, kemudian pelaku ojek meminta lebih besar dari apa yang ada di handphone pengguna, pelaku menunjukkan handphone melalui aplikasinya bahwa besarnya biaya telah ditentukan oleh aplikasi, karena data dari aplikasi telah ditentukan oleh perusahaan sehingga tidak dapat dimanipulasi.

Berdasarkan dari hasil wawancara ini ternyata masih ada yang kesalahan Informatika yang diberikan sehingga menimbulkan adanya miskomunikasi antara pengguna jasa dengan pelaku ojek, hal ini dapat saja terjadi karena aplikasi tersebut bekerja dengan secara otomatis, perbedaan tersebut dapat juga terjadi pada saat naik atau turun tidak pada tujuan yang telah ditentukan, karena biaya ojek berdasakan pada kilometer yang ditempuh. Untuk itu, perlu melakukan perlindungan terhadap pengguna jasa, perlindungan tersebut dapat dilaksanakan dengan perlindungan preventif, dan perlindungan represif.

Perlindungan preventif ini, subjek hukum diberikan kesempatan untuk mengajukan keberatan atau pendapatnya sebelum suatu keputusan pemerintah mendapat bentuk yang definitif, tujuannya adalah mencegah terjadinya sengketa.

Perlindungan preventif sangat besar artinya bagi tindak pemerintah yang didasarkan pada kebebasan bertindak karena dengan adanya perlindungan hukum yang preventif, pemerintah terdorong untuk bersifat hati-hati dalam mengambil keputusan yang didasarkan pada diskresi. Di Indonesia belum ada pengaturan khusus mengenai perlindungan hukum preventif. 
Perlindungan represif bertujuan untuk menyelesaikan sengketa.Penanganan perlindungan hukum oleh pengadilan umum dan peradilan administrasi di Indonesia termasuk kategori perlindungan hukum ini. Prinsip perlindungan hukum terhadap tindakan pemerintah bertumpu dan bersumber dari konsep tentang pengakuan dan perlindungan terhadap hak-hak asasi manusia.

Perlindungan pengguna jasa memiliki ruang lingkup yang luas dan sulit dibatasi, tidak bisa dirumuskan dalam satu undang-undang saja, misalnya UUPK. usaha dan/atau melindungi kepentingan pengguna jasa, merupakan hukum perlindungan pengguna jasa.

\section{Faktor-Faktor Yang Mendukung Adanya Ojek On line Kota Banjarmasin}

Perkembangan ojek on line ini sangat pesat sekali, karena sangat dibutuhkan oleh anggota masyarakat, terutma pada saat tertentu ada anggota masyarakat yang enggan keluar rumah atau enggan menggunakan kendaraan bermotor maka menggunakan jasa ojek on line ini.

Wawancara yang dilakukan pada tanggal 24 Juni 2018, kepada salah seorang pegawai dinas perhubungan dengan mengatakan sebagai berikut :

Faktor yang mendukung dari keberadaan ojek on line ini dipandang dari beberapa aspek, yaitu dari aspek ekonomi, ojek on line menciptakan lapangan pekerjaan baru, sehingga dapat meningkatkan pendapatan anggota masyarakat, dari segi sosial, ojek on line akan mengurangi angka pengangguran, mengurangi kemacetan arus lalu lintas. Dari segi hukum, adanya peraturan perundang-undangan yang dijadikan landasan untuk beroperasinnya ojek on line.

Berdasarkan pada hasil wawancara tersebut maka ada faktor yang mendukung dengan beroperasinya ojek onm line, yaitu

a. Segi ekonomi, maka pajak on line dapat menciptakan lapangan pekerjaan baru, karena pada saat ini lapangan pekerjaan sangat terbatas dan membutuhkan keahlian tertentu, dibandingkan dengan ojek on line yang hanya membutuhkan keterampilan mengendari kendaraan bermotor baik roda dua maupun roda empat, selanjutnya sebagai syarat untuk mengendarai kendaraan bermotor adalah SIM dan handphone yang ada program aplikasinya.

b. Segi sosial, adanya ojek on line akan mengurangi angka pengangguran dengan adanya lapangan pekerjaan anggota masyarakat tidak akan melakukan tindakan yang 
berlawanan dengan hukum, sehingga keamanan dan ketertiban akan kondusif, selain itu dapat mengurangi kemacetan arus lalu lintas, karena ada anggota masyarakat yang enggan untuk menggunakan kendaraan bermotor pada saat tertentu, demikian juga dengan anggota masyarakat yang enggan keluar rumah akan menggunakan jasa ojek on line untuk kegiatan-kegiatan tertentu, terutama mengantarkan paket.

c. Segi Hukum, adanya peraturan perundang-undangan yang menjadi landasan hukum untuk beroperasinya ojek on line, sehingga dapat menjamin keberlangsungan ojek on line ini.

\section{Faktor Yang Menghambat Adanya Ojek On line Kota Banjarmasin}

Sesuatu yang akan berkembang tidak selama dapat berjalan sesuai dengan apa yang diharapkan, karena faktor-faktor yang menghambat dalam perkembangan tersebut, demikian pula dengan keberadaan ojek on line ada faktor penghambat yang dirasakan sampai saat ini, hal ini sesuai dengan wawancara yang dilakukan kepada salah seorang dinas perhubungan kota Banjarmasin dengan mengatakan sebagai berikut;

Sesuatu yang berkembang tidak selama dapat berjalan mulus, tetapi ada hambatan-hambatan yang dirasakan untuk dapat mengembangkan sesuatu tersebut, demikian pula dengan keberadaan ojek on line, faktor penghambatnya adalah dilihat segi aspek hukum adalah belum adanya peraturan daerah yang dapat dijadikan acuan untuk menindalanjuti Peraturan Menteri 108 tahun 2017 tentang penyelengaraan angkutan orang dengan kendaraan bermotor umum tidak dalam trayek, ojek on linetermasuk didalamnya, termasuk petunjuk pelaksanaanya dan petunjuk teknisnya, selain itu, juga datang dari anggota masyarakat yang masih menggunakan ojek tradisional, sehingga ojek on line ini tidak bergerak secara leluasa.

Berdasarkan dari hasil wawancara tersebut maka faktor yang menghambat keberadaan ojke on line ini adalah

a. Produk hukum, berupa peraturan daerah yang dapat menjembati keberadaan ojek on line. Pada hal peraturan daerah ini sangat dibutuhkan oleh pelaku ojek on line, karena dasar hukumnya tidak hanya bersandar pada peraturan menteri semata, tetapi juga bersandar pada peraturan daerah, sedangka ojek on line menjadi lingkupnya dinas perhubungan dan komunikasi dan Informatika juga memerlukan adanya petunjuk 
pelaksanaan dan petunjuk teknis, dengan adanya kekuatan hukum ini maka dinas akan mengatur lebih lanjut tentang keberadaan ojek on line ini

b. Masih adanya wilayah-wilayah yang tidak dapat dimasuki oleh ojek on line, hal ini berkenaan dengan ojek yang masih bersifat tradisional, hal ini mengakibatkan tidak leluasanya ojek on line ini untuk beroperasi, atau melaksanakan kegiatan sehari-hari.

\section{KESIMPULAN}

Perkembangan ojek on line kota di Kota Banjarmasin mengalami peningkatan dari tahun ke tahun, walaupun demikian ojek on line ini masih belum sepenuhnya ditangani oleh dinas Perhubungan komunikasi dan Informatika, sehingga tidak ditemukan data yang akurat berapa jumlah ojek on line ini.

Faktor mendukung dari keberadaan ojek on line ini dipandang dari beberapa aspek, yaitu dari aspek ekonomi, ojek on line menciptakan lapangan pekerjaan baru, sehingga dapat meningkatkan pendapatan anggota masyarakat, dari segi sosial, ojek on line akan mengurangi angka pengangguran, mengurangi kemacetan arus lalu lintas. Dari segi hukum, adanya peraturan perundang-undangan yang dijadikan landasan untuk beroperasinnya ojek on line.

Faktor yang menghambatnya perkembangan ojke on line adalah dilihat segi aspek hukum adalah belum adanya peraturan daerah yang dapat dijadikan acuan untuk menindalanjuti Peraturan Menteri 108 tahun 2017 tentang penyelengaraan angkutan orang dengan kendaraan bermotor umum tidak dalam trayek, termasuk petunjuk pelaksanaanya dan petunjuk teknisnya, selain itu, juga datang dari anggota masyarakat yang masih menggunakan ojek tradisional, sehingga ojek on line ini tidak bergerak secara leluasa.

\section{DAFTAR PUSTAKA}

Atmosudirdjo, Prayudi, 2013. Administrasi Perkantoran Suatu Pengantar. Penerbit CV. Rajawali Jakarta

Thoha, Miftah, 2012. Administrasi Negara dan Publik dalam Era Raformasi. Penerbit Gramedia Jakarta

Waldo, Dwight, 1965. Pengantar Studi Publik Administration, terjemahSlamet W. Adena Sodono. Penerbit Radar jaya Ofset Jakarta 
Volume 5 Nomor 1, April 2019

Raharjo, Budi, 2014. Transportasi dan Komunikasi Penerbit Gramedia Jakarta

Nawawi, Hadari, 2010. Manajemen Strategik, Organisasi Non Profit Bidang Pemerintahan dengan Ilustrasi di Bidang Pendidikan. Penerbit Gajah Mada University Press Yogyakarta.

Singarimbun, Masri, 2012. Metodologi Penelitian Sosial. Penerbit Gramedia jakarta

Nitisemito, Alek S, 2010. Manajemen Pemasaran. Penerbit Rineka Cipta Jakarta

Sukarna, 2011. Pengantar Administrasi Publik. Penerbit CV. Alfabeta Bandung

S. P. Siagian, 2011. Filsafat Administrasi. Penerbit Ghalia Indonesia Jakarta

Soekamto, 2013. Implementasi Administrasi Transportasi. Penerbit Gadjah Mada University Press Yogyakarta

Peraturan Menteri Perhubungan Nomor 108 Tahun 2017. Tentang Penyelenggaraan Angkutan Orang dengan Kendaraan Bermotor Umum Tidak dalam Trayek 